\title{
EVALUATION OF IN VITRO CYTOTOXIC AND ANTICANCER ACTIVITY OF HEPATOPROTECTIVE POLYHERBAL FORMULATION IN CELL LINE MODEL
}

\author{
JAYACHANDRA KUNCHA ${ }^{1 *}$, THIRUGNANASAMBANTHAM ${ }^{2}{ }^{2}$, KUMARAN $\mathbf{S}^{1}$, NARAYANAN $\mathbf{N}^{3}$, SHARMILA DEVI ${ }^{4}$ \\ ${ }^{1}$ Department of Biotechnology, Periyar Maniammai Institute of Science and Technology, Thanjavur, Tamil Nadu, India. ${ }^{2}$ Rumi Herbals \\ R and D Centre, Chennai, Tamil Nadu, India. ${ }^{3}$ Department of Pharmaceutics, A.J College of Pharmacy, Chennai, Tamil Nadu, India, \\ ${ }^{4}$ Department of Biochemistry, Captain Srinivasa Murthy Regional Ayurveda Drug Development Institute, Chennai, Tamil Nadu, India. \\ Email: jayachandrakuncha@gmail.com
}

Received: 23 January 2019, Revised and Accepted: 22 March 2019

\section{ABSTRACT}

Objective: The use of natural products as anticancer agents has a long history that began with folklore medicine and through the years has been incorporated into traditional and allopathic medicine. Several drugs currently used are derived from medicinal plants.

The main objective of this study is to investigate the cytotoxic potential of hepatoprotective polyherbal formulation in normal and cancer cell lines.

Methods: A 3-(4,5-dimethythiazol-2-yl)-2,5-diphenyltetrazolium bromide assay was utilized to screen the cytotoxic activity.

Results: The results revealed that the formulation does not induce much mortality in normal liver and kidney cell lines, and $\mathrm{LC}_{50}$ value of liver cell lines was found $1716.355 \mu \mathrm{g} / \mathrm{ml}$ and kidney cell lines $2464.910 \mu \mathrm{g} / \mathrm{ml}$. The in vitro anticancer activity was performed on liver, colon, and prostate cancer cell lines, and $\mathrm{IC}_{50}$ values are found $2.077,3.850$, and $11.989 \mu \mathrm{g} / \mathrm{ml}$, respectively, which show excellent anticancer activity.

Conclusion: Based on the results obtained, the hepatoprotective polyherbal formulation is safe for normal cells and cytotoxic for cancer cells. Further, identification and quantification of phytoconstituents responsible for the activity are in progress.

Keywords: Polyherbal formulation, Phytochemicals, Cytotoxicity, Anticancer activity.

(C) 2019 The Authors. Published by Innovare Academic Sciences Pvt Ltd. This is an open access article under the CC BY license (http://creativecommons. org/licenses/by/4. 0/) DOI: http://dx.doi.org/10.22159/ajpcr.2019.v12i4.32118

\section{INTRODUCTION}

In recent years, most of the world population is witnessing medicine going back to nature - a shift in global trend from synthetic to natural medicine. In the ancient days also, medicinal herbs are used to treat several diseases. Even today for health maintenance, the Indian traditional medical systems such as Ayurveda, Siddha, Unani, Homeopathy, Yoga, and Naturopathy are practiced and accepted by worldwide population. Nowadays, more research is going on phytomedicine, and several botanical preparations are evaluated for its potential therapeutic efficacy. Among those botanical drugs, anticancer and hepatoprotective agents are standing in front [1]. Oncology-related cases are increasing day by day due to environmental pollution, food, and lifestyle modifications. Currently, cancer is treated by chemotherapy, surgery, and radiation therapy. Most of the synthetic anticancer drugs are used for the treatment which show severe adverse effects [2]. Recently, most of the oncology-related researchers are trying to identify botanical preparations which show maximum anticancer effect with a minimum side effect. Semisynthetic or isolated active components from botanical origin such as Catharanthus roseus, Taxus brevifolia, Podophyllum emodi, and Camptotheca acuminata have been used in the treatment cancer [3]. The selected polyherbal formulation is made up of hydroalcoholic extract of different indigenous medicinal plants with specific ratio. The main objective of this study is to investigate cytotoxic potential and anticancer activity of a polyherbal ayurvedic formulation in cell line model.

\section{METHODS}

Chemicals and cell lines

All the required chemicals and reagents are analytical grade and procured from Loba Chemie Laboratory Reagents and HiMedia. The cell lines were obtained from the National Center for Cell Sciences,
Pune, India, and grown on Dulbecco's Modified Essential Medium supplemented with $10 \%(\mathrm{v} / \mathrm{v})$ fetal calf serum, penicillin $(100 \mathrm{U} / \mathrm{ml})$, and streptomycin $(100 \mu \mathrm{g} / \mathrm{ml})$.

\section{Preparation of hydroalcoholic extract}

The formulation is made up of five herbal ingredients in different ratios. Phytochemical extraction was done by cold maceration method using double-distilled water and ethanol in the ratio of 7:3 and kept for $48 \mathrm{~h}$ by occasional shaking. The residue was filtered through double-lined muslin cloth and evaporated to dryness under reduced pressure using vacuum evaporator. The resulting greenish-black material (LVR05) was kept in an airtight container at $4^{\circ} \mathrm{C}$.

Determination of in vitro cytotoxicity and anticancer activity In vitro cytotoxicity and anticancer activity were assessed by 3-(4,5-dimethythiazol-2-yl)-2,5-diphenyltetrazolium bromide (MTT) assay [4-9]. Two different experiments were carried out using the same procedure for assessing cytotoxicity and anticancer efficacy of test drug, and the percentage of cell viability and mortality was calculated using standard formula.

\section{RESULTS AND DISCUSSION}

\section{In vitro cytotoxicity studies}

The in vitro cytotoxicity studies give us a good idea about advantages and disadvantages of the model for screening and mechanistic analysis of potentially toxic compounds. A wide array of morphologic and biochemical markers are available for obtaining information at the cellular and molecular levels to detect chemical-induced disruption [10]. Among the methods, in vitro cell line models are quite easy to perform in laboratory conditions. Different concentrations of LVR05 were tested against normal liver and kidney cell lines, and the toxicity was assessed 
by MTT assay (Tables 1 and 2) and calculated $\mathrm{LC}_{50}$ using lethal dose probability line software (Figs. 1 to 10 ).
In vitro cytotoxicity data are useful for assessing the toxicity of particular material and also indicate the need for specific kinds

Table 1: Cytotoxic effect of different concentrations of LVR05 on normal cell lines (Chang liver cells)

\begin{tabular}{|c|c|c|c|c|}
\hline S. No & Concentration $(\mu \mathrm{g} / \mathrm{ml})$ & Absorbance (O.D) & Cell mortality (\%) & Cell viability (\%) \\
\hline 1 & 500 & 0.89 & 29.92 & 70.07 \\
\hline 2 & 250 & 0.95 & 25.19 & 74.80 \\
\hline 3 & 125 & 1.02 & 19.68 & 80.31 \\
\hline 4 & 62.5 & 1.10 & 13.38 & 86.61 \\
\hline 5 & 31.25 & 1.18 & 7.08 & 92.91 \\
\hline 6 & 15.63 & 1.21 & 4.72 & 95.27 \\
\hline 7 & 7.81 & 1.25 & 1.57 & 98.42 \\
\hline
\end{tabular}

Table 2: Cytotoxic effect of different concentrations of LVR05 on normal kidney cell lines (vero cells)

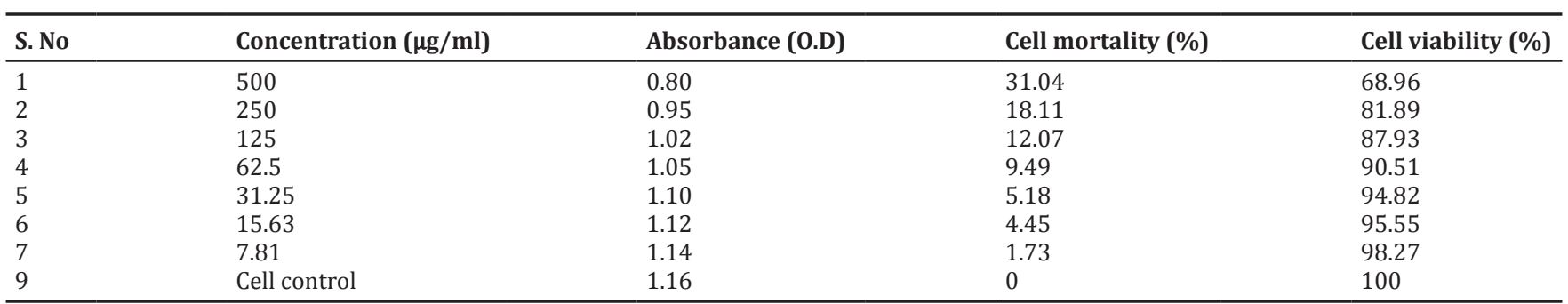

$\mu$ g: Micrograms, O.D: Optical density, LVR05: Hepatoprotective polyherbal formulation

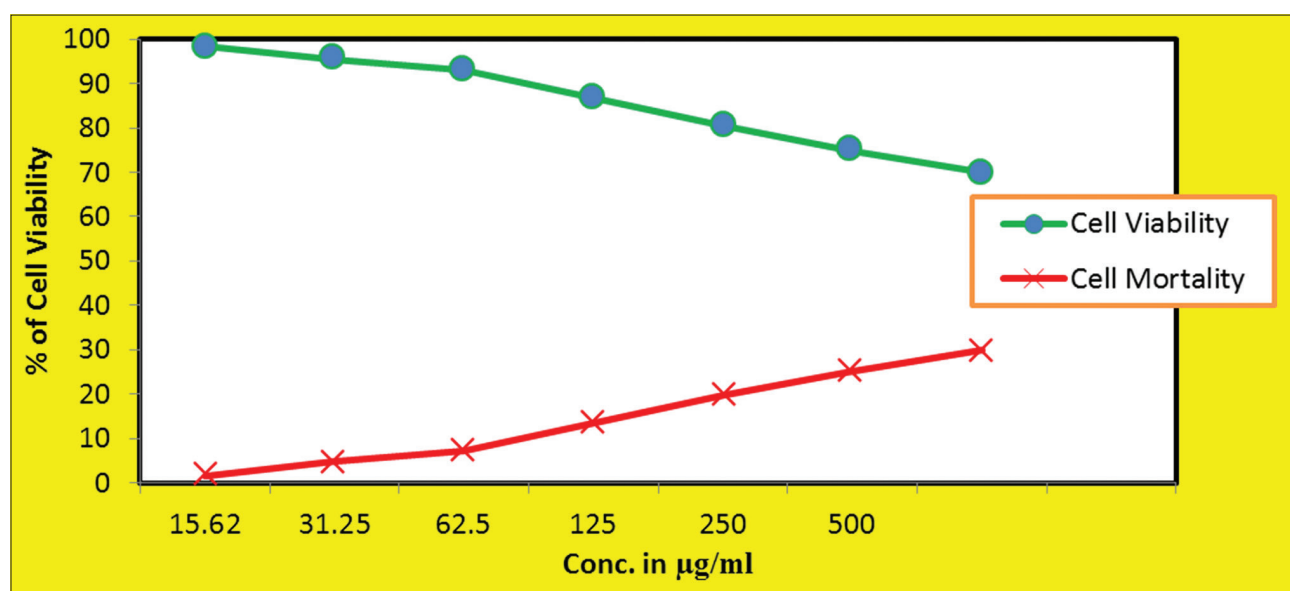

Fig. 1: Cytotoxic effect of LVR05 on normal liver cell lines percentage of viability and mortality

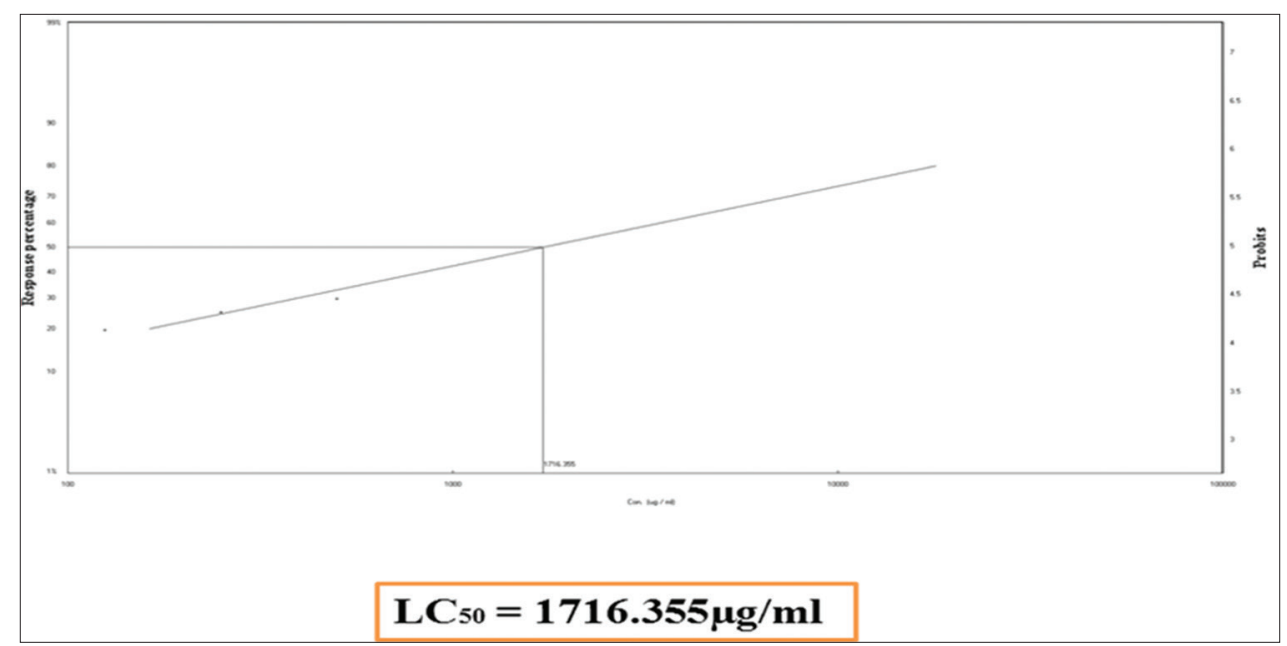

Fig. 2: $\mathrm{LC}_{50}$ value of LVR05 on normal liver cell lines was calculated by lethal dose probability line software 


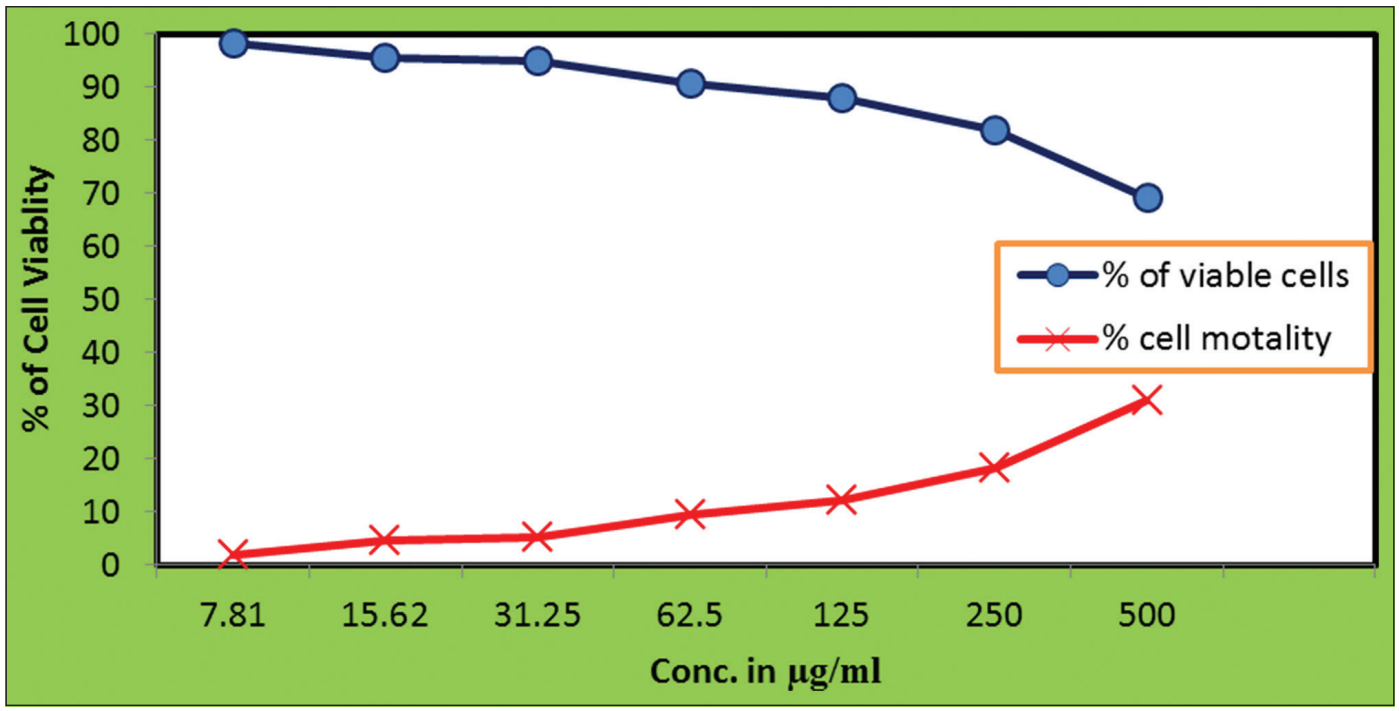

Fig. 3: Cytotoxic effect of LVR05 on normal kidney (vero) cell lines percentage of viability and mortality

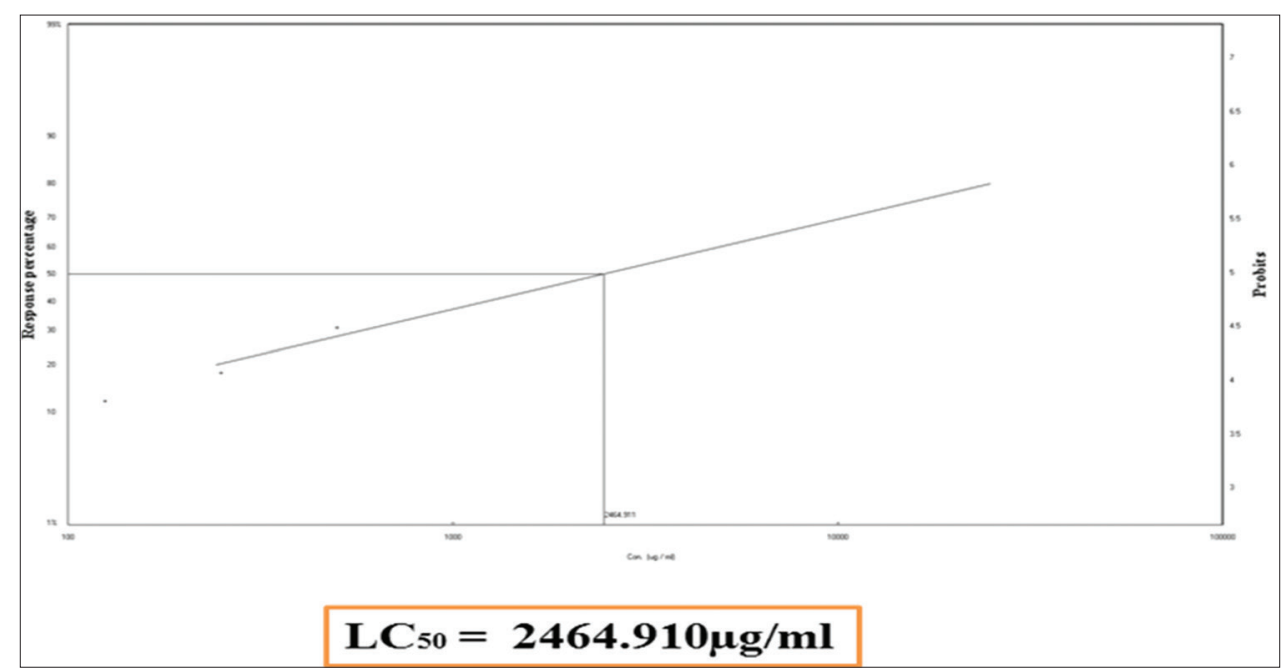

Fig. 4: $\mathrm{LC}_{50}$ calculation by lethal dose probability line software

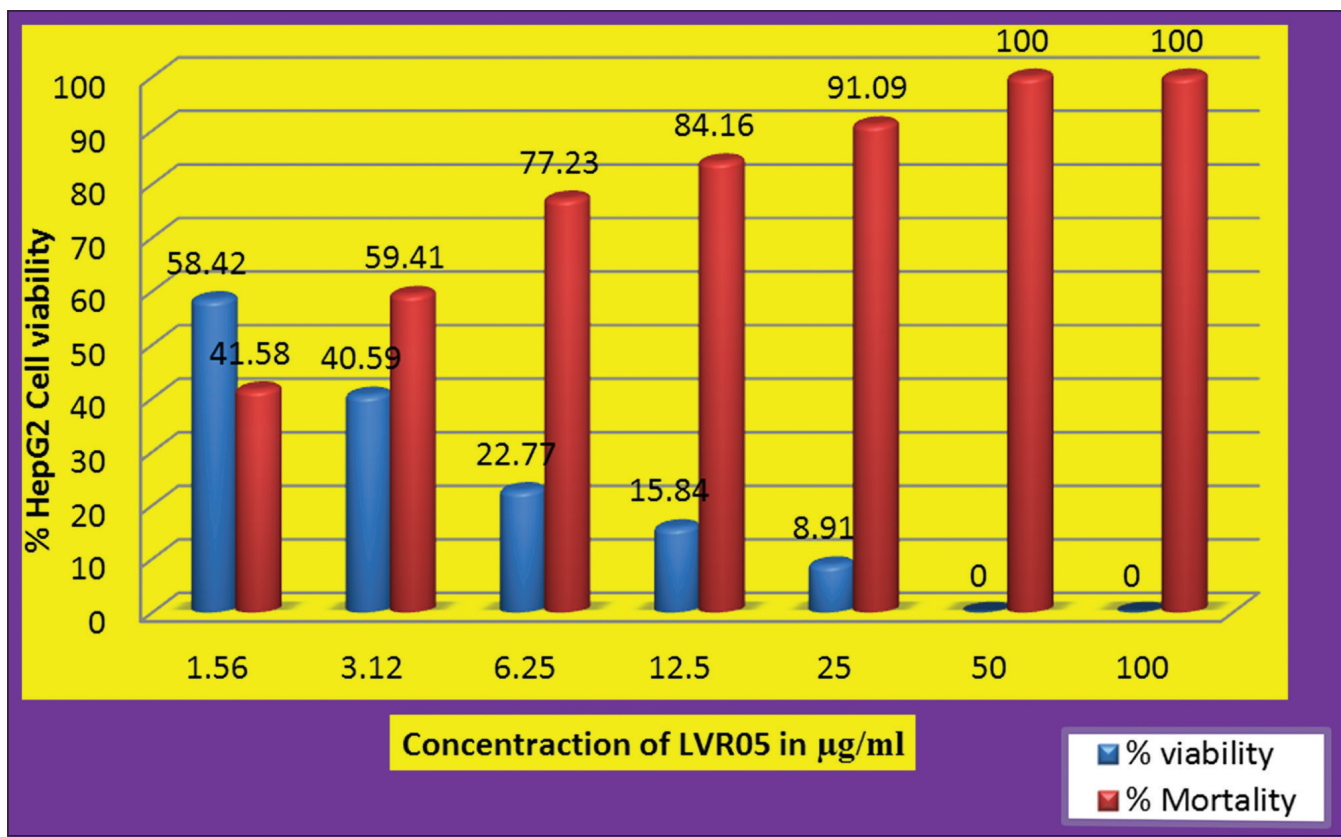

Fig. 5: Anticancer activity of different concentrations of LVR05 on liver cancer $\left(\mathrm{HepG}_{2}\right)$ cell lines 


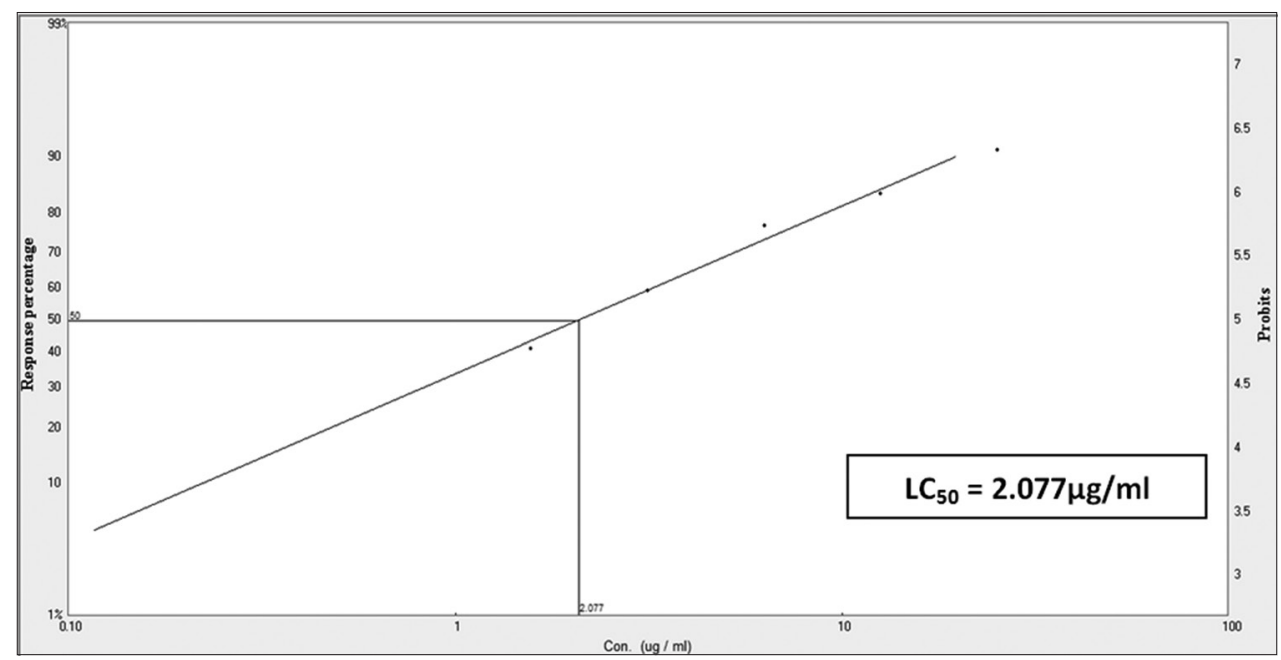

Fig. 6: $\mathrm{LC}_{50}$ calculation by lethal dose probability line software

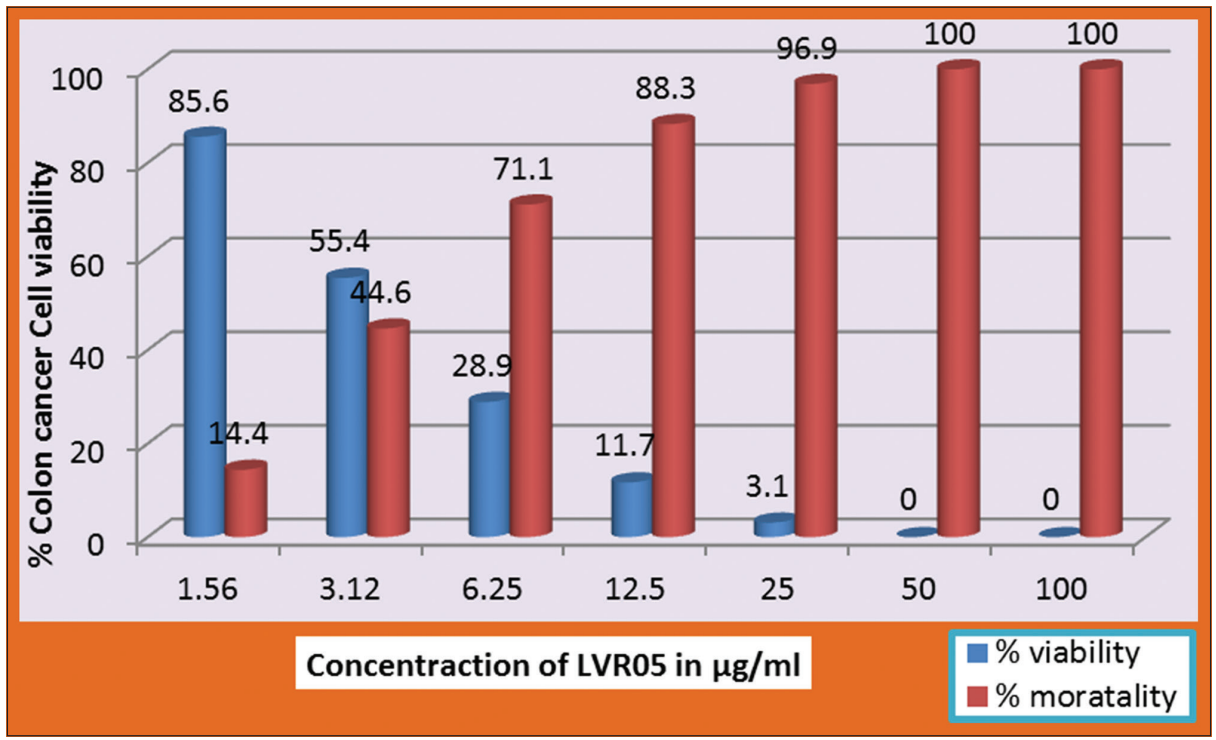

Fig. 7: Anticancer activity of different concentrations of LVR05 on colon cancer cell lines

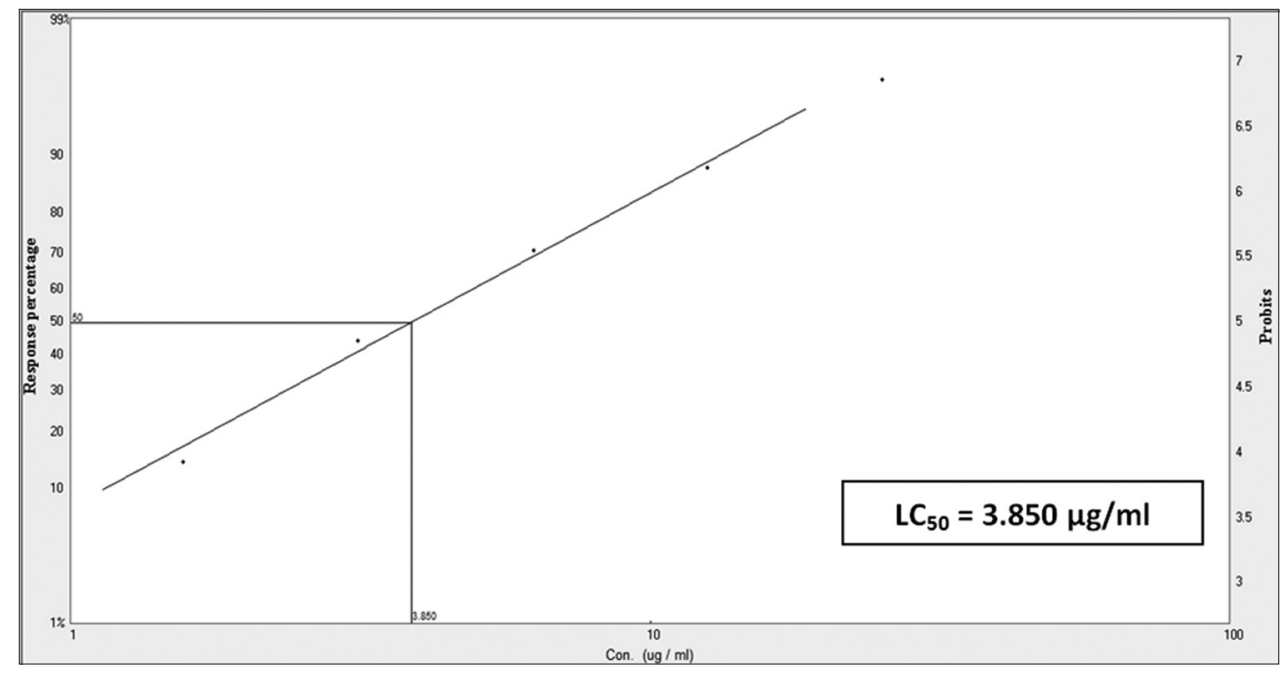

Fig. 8: $\mathrm{LC}_{50}$ calculation by lethal dose probability line software 


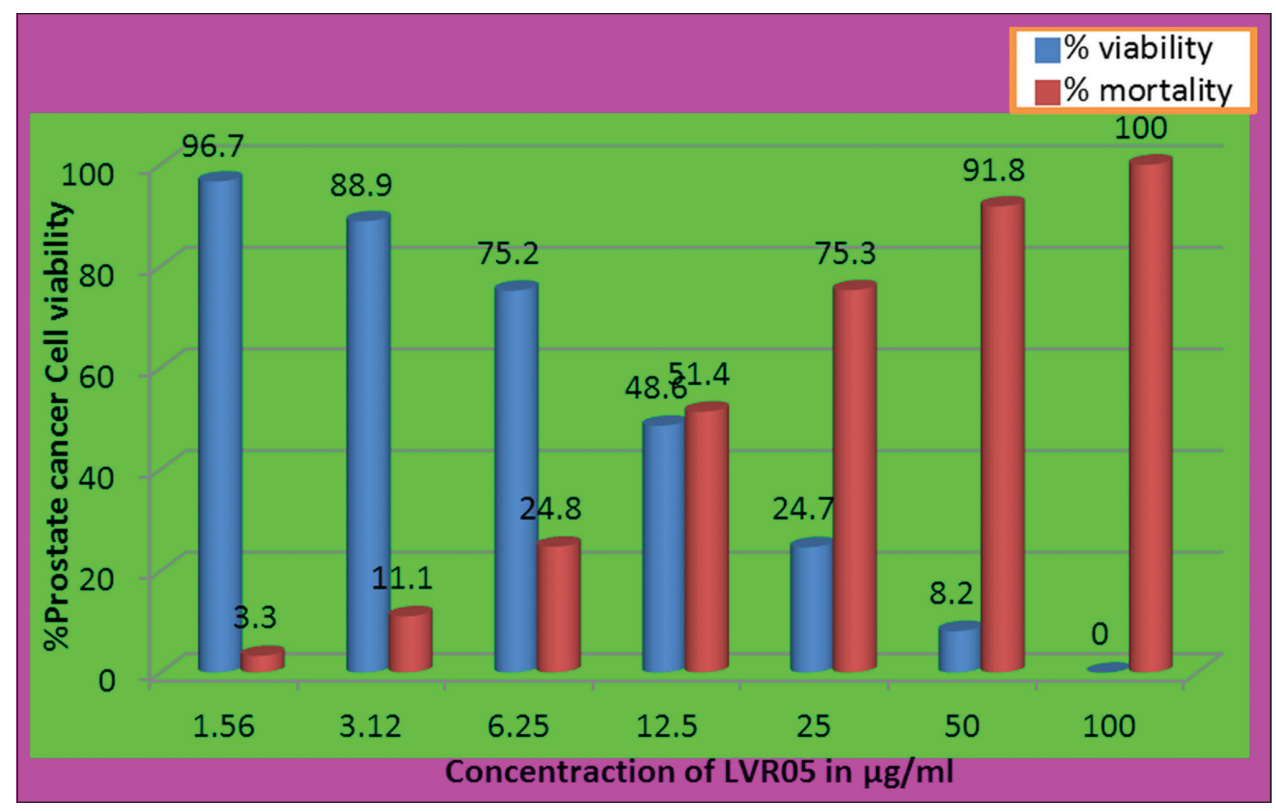

Fig. 9: Anticancer activity of different concentrations of LVR05 on prostate cancer cell lines

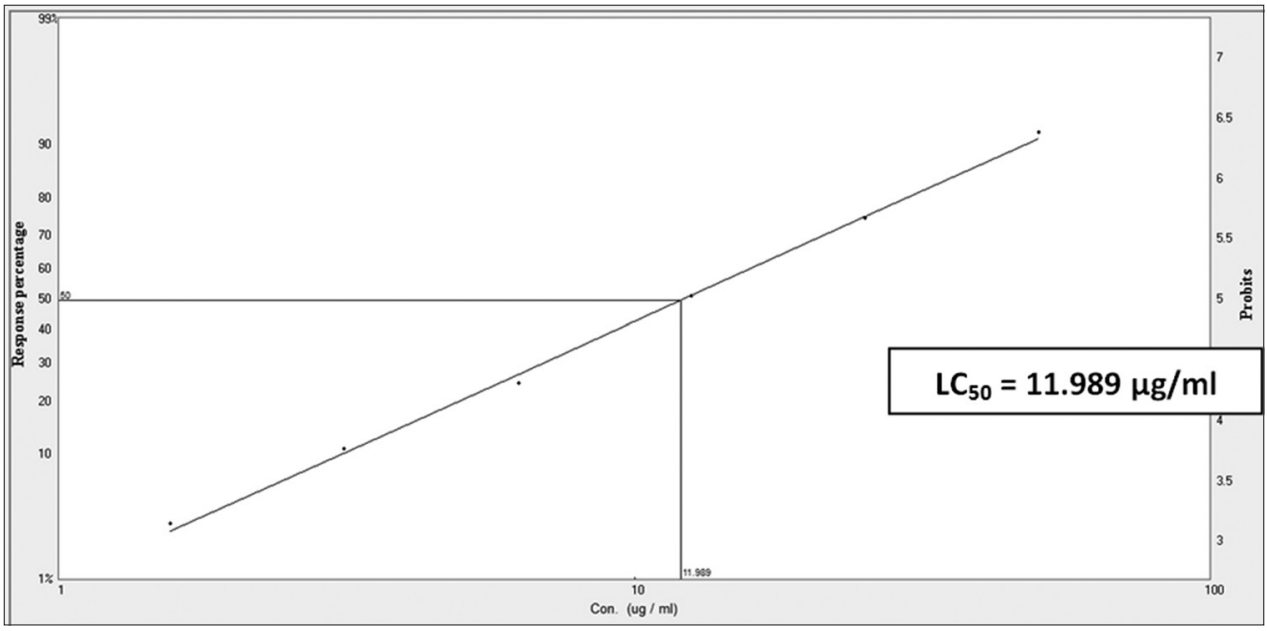

Fig. 10: $\mathrm{LC}_{50}$ calculation by lethal dose probability line software

of additional toxicity tests that would be required. Any drug administered in to the system, undergoes metabolism in the liver. The liver is the primary organ which is exposed more to the drugs and toxicants. After the metabolism completed, it should eliminate through the kidney. During the elimination process, there are chances of causing damage to the kidney cells. Based on the results obtained from the cytotoxic activity, the polyherbal formulation does not induce any abnormality in normal liver and kidney cells which indicates its safety.

\section{In vitro anticancer studies}

Cellular screening in cancer research mainly consists of human tumor cell lines. It is the most suitable system in terms of management and reproducibility [11]. Currently, different concentrations of LVR05 were tested against liver, colon, and prostate cell lines and results found very effective.

Liver cancer or hepatocellular carcinoma has a low survival rate, and major risk factors include excessive alcohol intake, hepatitis, smoking, and high-grade fatty liver. Symptoms generally appear when cancer reaches an advanced stage. Treatment options for liver cancer include surgery and liver transplantation [12]. There is a huge demand for safe and promising therapeutic agents which can reduce the incidence of liver cancer. Based on results obtained, the polyherbal formulation shows potent anticancer activity in dosedependent manner. Even at low concentration $(50 \mu \mathrm{g} / \mathrm{ml})$, there was no cancerous cell viable which indicates the anticancer efficacy of the formulation.

Colon cancer is cancer of the large intestine (Colon), which is the final part of the digestive tract. Colon cancer starts with small, noncancerous clumps of cells called adenomatous polyps. These polyps can become cancerous when continuous inflammation occurs in the colon. Till date, it is not clear what causes colon cancer and the cases of colon cancer are increasing $[13,14]$. The formulation is inhibiting the growth of colon cancer cells in dose dependent manner. At the concentration of $25 \mu \mathrm{g} / \mathrm{ml}$, cancer cell viability was $3.1 \%$ and mortality $96.9 \%$. At the concentration of $50 \mu \mathrm{g} / \mathrm{ml}$ there was no growth at all.

The incidence of prostate cancer is one of the most widespread cancer diagnoses in every part of the world. The pathogenesis of prostate cancer has remained a perplex issue [15]. In this study, the LVR05 inhibits prostate cancer cell growth $91.8 \%$ at the concentration of $50 \mu \mathrm{g} / \mathrm{ml}$. 


\section{CONCLUSION}

Based on the above results, it is concluded that the polyherbal formulation has not induced much toxicity in normal liver and kidney cell lines which indicate safe when taken internally. The hydroalcoholic extract possesses excellent anticancer activity on liver, colon, and prostate cancer cell lines. Further, identification and quantification of phytoconstituents responsible for the activity are in progress.

\section{ACKNOWLEDGMENT}

The author is thankful to the Director, Rumi Herbals Pvt. Ltd, Chennai, for providing test drug as a gift sample and necessary facilities to carry out the work.

\section{AUTHORS' CONTRIBUTION}

Research work was designed and executed by the corresponding author under the guidance of second, third, and fourth authors and technically supported by fifth author.

\section{CONFLICTS OF INTEREST}

All the authors declared no conflicts of interest. The major part of the work was handled by the corresponding author. Remaining authors are contributed in the required places.

\section{REFERENCES}

1. Ilyas U, Katare DP, Aeri V, Naseef PP. A review on hepatoprotective and immunomodulatory herbal plants. Pharmacogn Rev 2016;10:66-70.

2. Patel S, Gheewala N, Suthar A, Shah A. In-vitro cytotoxicity activity of Solanum nigrum extract against Hela cell line and Vero cell line. Int J Pharm Pharm Sci 2009;1 Suppl 1:38-46.

3. Jiménez-Medina E, Garcia-Lora A, Paco L, Algarra I, Collado A, Garrido F, et al. A new extract of the plant Calendula officinalis produces a dual in vitro effect: Cytotoxic anti-tumor activity and lymphocyte activation. BMC Cancer 2006;6:119.

4. Fotakis G, Timbrell JA. In vitro cytotoxicity assays: Comparison of LDH, neutral red, MTT and protein assay in hepatoma cell lines following exposure to cadmium chloride. Toxicol Lett 2006;160:171-7.

5. Stone V, Johnston H, Schins RP. Development of in vitro systems for nanotoxicology: Methodological considerations. Crit Rev Toxicol 2009;39:613-26.

6. Vijayabaskaran M, Venkateswaramurthy N, Pasha A, Babu G, Sivakumar P, Perumal P, et al. In vitro cytotoxic effect of ethanolic extract of Pseudarthria viscida Linn. Int J Pharm Pharm Sci 2010;2:93-4.

7. Sharma S, Kumar VN. In vitro cytotoxicity effect on MCF-7 cell line of co-encapsulated artesunate and curcumin liposome. Int J Pharm Pharm Sci 2017;9:123-8.

8. Mosmann T. Rapid colorimetric assay for cellular growth and survival: Application to proliferation and cytotoxicity assays. J Immunol Methods 1983;65:55-63.

9. Präbst K, Engelhardt H, Ringgeler S, Hübner H. Basic colorimetric proliferation assays: MTT, WST, and resazurin. Methods Mol Biol 2017;1601:1-7.

10. Tyson CA, Green CE. Cytotoxicity measures: Choices and methods in the isolated hepatocyte, In: Rauckman EG, Padilla GM, editors. Use in Toxicology and Xenobiotic Biotransformations. Orlando, FL: Academic Press; 1987. p. 119-58.

11. Boyd MR, Paull KD. Some practical considerations and applications of the national cancer institute in vitro anticancer drug discovery screen. Drug Dev Res 1995;34:91-9.

12. González LT, Minsky NW, Espinosa LE, Aranda RS, Meseguer JP, Pérez PC, et al. In vitro assessment of hepatoprotective agents against damage induced by acetaminophen and $\mathrm{CCl}_{4}$. $\mathrm{BMC}$ Complement Altern Med 2017;17:39.

13. Manosroi A, Akazawa H, Akihisa T, Jantrawut P, Kitdamrongtham W, Manosroi $\mathrm{W}$, et al. In vitro anti-proliferative activity on colon cancer cell line (HT-29) of thai medicinal plants selected from thai/Lanna medicinal plant recipe database "MANOSROI III". J Ethnopharmacol 2015;161:11-7.

14. Prashant A, Rangaswamy C, Yadav AK, Reddy V, Sowmya MN, Madhunapantula $\mathrm{S}$, et al. In vitro anticancer activity of ethanolic extracts of Piper nigrum against colorectal carcinoma cell lines. Int J Appl Basic Med Res 2017;7:67-72.

15. Shridhar C, Ghagane A, Sridevi I, Puranik SI, Kumbar VM, Rajendra B, et al. In vitro antioxidant and anticancer activity of Leea indica leaf extracts on human prostate cancer cell lines. Integr Med Res 2017;6:79-7. 